\title{
Emerging Yr26-Virulent Races of Puccinia striiformis f. tritici Are Threatening Wheat Production in the Sichuan Basin, China
}

\begin{abstract}
D. J. Han, State Key Laboratory of Crop Stress Biology for Arid Areas and College of Agronomy, and Q. L. Wang, State Key Laboratory of Crop Stress Biology for Arid Areas and College of Plant Protection, Northwest A\&F University, Yangling, Shaanxi, P. R. China; X. M. Chen, Wheat Genetics, Quality, Physiology, and Disease Research Unit, United States Department of Agriculture-Agricultural Research Service, and Department of Plant Pathology, Washington State University, Pullman 99164-6430; Q. D. Zeng and J. H. Wu, State Key Laboratory of Crop Stress Biology for Arid Areas and College of Plant Protection, W. B. Xue, State Key Laboratory of Crop Stress Biology for Arid Areas and College of Agronomy, and G. M. Zhan, L. L. Huang, and Z. S. Kang, State Key Laboratory of Crop Stress Biology for Arid Areas and College of Plant Protection, Northwest A\&F University
\end{abstract}

\begin{abstract}
Han, D. J., Wang, Q. L., Chen, X. M., Zeng, Q. D., Wu, J. H., Xue, W. B., Zhan, G. M., Huang, L. L., and Kang, Z. S. 2015. Emerging Yr26-virulent races of Puccinia striiformis f. tritici are threatening wheat production in the Sichuan Basin, China. Plant Dis. 99:754-760.

Stripe rust, caused by Puccinia striiformis f. tritici, is one of the most destructive diseases of wheat in the world. The Sichuan Basin is one of the most important regions of wheat production and stripe rust epidemics in China. Stripe rust resistance gene $\operatorname{Yr} 26$ (the same gene as Yr24) has been widely used in wheat breeding programs and in many cultivars grown in this region since the gene was discovered in the early 1990 s. Virulence to $\operatorname{Yr} 26$ has increased in frequency since its first detection in 2008. The objective of this study was to assess the vulnerability of the wheat cultivars and breeding lines in the Sichuan Basin to Yr26-virulent races. In total, 85 wheat accessions were tested with Yr26-avirulent races CYR32, CYR33, and Su11-4 and two Yr26-virulent races, V26/CM42 and V26/Gui22. DNA markers for $Y r 26$ were used to

determine the presence and absence of $Y r 26$ in the wheat accessions. Of the 85 wheat accessions, only 5 were resistant and 19 susceptible to all races tested, and the remaining 61 were resistant to at least one or more races tested in seedling stage. In all, $65(76.5 \%)$ accessions were susceptible to the emerging $\operatorname{Yr} 26$-virulent race V26/Gui22. In field tests, susceptible accessions increased from $31.8 \%$ in a nursery inoculated with predominant and $\mathrm{Yr} 26$-avirulent races to $61.2 \%$ in the nursery inoculated with the predominant races mixed with V26/Gui22. Based on the results of the molecular marker and race tests, $33(38.8 \%)$ accessions were determined to have $\operatorname{Yr26}$, showing that the $\operatorname{Yr} 26$ virulence is a major threat to wheat production in the Sichuan Basin and potentially in other regions of China.
\end{abstract}

Stripe rust, caused by Puccinia striiformis f. sp. tritici Erikss., is one of the most important diseases of wheat (Triticum aestivum L.) worldwide $(6,10,34,36)$. Because $P$. striiformis $\mathrm{f}$. tritici urediniospores of the fungal pathogen can be disseminated by wind over long distances, the fungal pathogen is able to cause large-scale epidemics, resulting in huge yield losses if no control measures are taken (1). In China, nationwide stripe rust epidemics resulting in huge yield losses or wide application of fungicides occurred in 1950, 1964, 1990, and 2002, with the disease occurring more frequently in the northwestern and southwestern regions where the pathogen can oversummer or overwinter $(5,15,17,30,32)$. Every devastating epidemic was related to the appearance and development of new $P$. striiformis f. tritici races. Growing resistant cultivars is the most economical and effective strategy for sustainable control of the disease $(6,9,23)$. Currently, more than 60 permanently named genes ( $\mathrm{Yrl}$ to $\mathrm{Yr} 67$ ) and numerous temporarily designated genes have been reported in wheat for stripe rust resistance and most of them have been used in wheat breeding programs worldwide $(7,11,20,22,26)$. However, many of the race-specific resistance genes have been overcome by new virulent races of $P$. striiformis f. tritici, which have resulted in large-scale epidemics $(8,9,34)$.

\section{J. Han and Q. L. Wang contributed equally to this work.}

Corresponding authors: Z. S. Kang; E-mail: kangzs@nwsuaf.edu.cn; and L. L. Huang; E-mail: huanglili@nwsuaf.edu.cn

Accepted for publication 28 November 2014.

http://dx.doi.org/10.1094/PDIS-08-14-0865-RE

(c) 2015 The American Phytopathological Society
Stripe rust resistance gene $Y r 26$ (the same gene as $Y r 24$ ) (16) was initially identified in a series of wheat-Haynaldia villosa $6 \mathrm{AL} / 6 \mathrm{VS}$ translocation lines, such as 92R137, 92R149, and 92R078, developed by Chen et al. $(3,4,21)$ in Nanjing Agricultural University and released in the early 1990s. Because of its high level resistance to predominant P. striiformis f. tritici races, including CYR32 and CYR33, Yr26 has been widely deployed in the major stripe-rust-prone regions in China, especially the Sichuan Basin. Virulence to $\mathrm{Yr} 26$ was first detected on 'Chuanmai 42' wheat in the Sichuan Basin in 2008 (19) and subsequently in Gansu on line 92R137 and Guinong 22 (13); which have been widely used in breeding programs in these regions. In 2010, Yr26-virulent races were detected at low frequencies from samples collected from highly susceptible 'Mingxian 169' and 92R137. However, moderate to severe stripe rust was observed on cultivars with $Y r 26$, including 'Neimai 8' and 'Lantian 17' in 2011. Since then, the frequency of $Y r 26$-virulent races has increased from 3.4\% in 2011 to $10.3 \%$ in 2013 (Z. S. Kang and associates, unpublished data). Moreover, several races virulent to $\operatorname{Yr} 26$ have been detected in the recent years in many provinces, including Sichuan, Gansu, Shaanxi, Qinghai, and Ningxia. The initial Yr26-virulent race has a narrow virulence range but different Yr26virulent races identified more recently have wider virulence spectra.

The stripe rust pathogen is capable of long-distance dispersal, and epidemiological regions can be characterized as oversummering, overwintering, or spring epidemic zones based on climatic conditions and cropping systems for the pathogen $(1,5,28,38)$. The Sichuan Basin, which is about $260,000 \mathrm{~km}^{2}$ and located in southwestern China (Fig. 1), plays an important role in stripe rust epidemics in China $(12,15,17)$. Wheat crops in the basin are infected in the autumn by urediniospores disseminated from the surrounding mountainous $P$. striiformis f. tritici-oversummering areas. In the basin, the mild 
and often moist winter allows wheat to grow and the $P$. striiformis $\mathrm{f}$. tritici fungus to survive, sporulate, and even infect wheat crops in multiple cycles (12). Therefore, the basin is considered to be a reservoir of $P$. striiformis f. tritici inoculum for spreading to other regions, and the early occurrences of stripe rust are used to predict stripe rust epidemics for the region and other regions farther east $(5,15,39)$. The dynamics of the pathogen population is strongly influenced by the distribution of resistance genes in the host population $(2,14)$. Given the Yr26-virulent races started in the Sichuan Basin, the presence of $Y r 26$ in the wheat cultivars grown in the region should have affected the race structure changes in the region and other regions. Although Yr26-virulent races have caused only localized damage thus far, a better understanding of the potential threat by the races through determining the distribution of $Y r 26$ in wheat cultivars and breeding lines in the region and their resistance or susceptibility to predominant races and those virulent to $\operatorname{Yr} 26$ should reduce potential risk. Therefore, the objectives of this study were to determine resistance or susceptibility of wheat cultivars and breeding lines from the Sichuan Basin to the emerging $Y r 26$-virulent races and the presence and absence of $Y r 26$ in the cultivars and breeding lines. The results will be useful in assessing the epidemic risks posed by the new race group and will guide proper strategies for control of the disease through changing wheat cultivars in production and resistance sources in breeding programs.

\section{Materials and Methods}

Wheat materials and $\boldsymbol{P}$. striiformis $\mathbf{f}$. tritici races. A collection of 85 wheat accessions, including 70 cultivars and 15 breeding lines grown or developed in the Sichuan Basin, was obtained from Sichuan Agriculture University and tested for stripe rust reaction and presence or absence of $Y r 26$. The wheat accessions and their pedigree and year of release are listed in Table 1. Five $P$. striiformis f. tritici races that had been determined by a set of Chinese wheat differentials were used in this study, including the three predominant races (CYR33, CYR32, and Su11-4) during 2011 to $2013(5,13)$, which are avirulent to $\mathrm{Yr} 26$, and two Yr26-virulent races, V26/ CM42 isolated from Chuanmai 42 in 2008 and V26/Gui22 isolated from Guinong 22 in 2012. The virulence or avirulence patterns of the races were determined using $17 Y r$ single-gene lines $(31,35)$, the recurrent susceptible parent Avocet S (AvS), and Yr26 donor lines 92R137 and Guinong 22 (Table 2).

Stripe rust tests in the greenhouse. Seedling evaluations for reaction to stripe rust were conducted in a greenhouse. Ten seeds of each accession were sown in a pot of 9 by 9 by $9 \mathrm{~cm}$. Mingxian 169 was used as a susceptible control. Seedlings at the two-leaf stage
(14 days after planting) were inoculated with urediniospores of a $P$. striiformis f. tritici race. The inoculated plants were incubated at $10^{\circ} \mathrm{C}$ in a dew chamber in the dark for $24 \mathrm{~h}$, then transferred to a greenhouse at $17 \pm 2{ }^{\circ} \mathrm{C}$ with $14 \mathrm{~h}$ of light $(22,000 \mathrm{~lx})$. Infection types (ITs) were scored 20 days after inoculation using a 0-to- 9 scale described by Line and Qayoum (18). Plants with ITs 0 to 6 were considered resistant and the inoculated race avirulent; and plants with ITs 7 to 9 were considered susceptible and the race virulent. All seedling tests were repeated at least two times to confirm and clarify infection types.

Stripe rust tests in the fields. To evaluate resistance or susceptibility of adult plants of the wheat accessions to the predominant races and $\mathrm{Yr} 26$-virulent races, the evaluations for resistance in the adult plant stage were conducted in two nurseries on the Northwest A\&F University research farms in Yangling, Shaanxi in the 2012-13 wheat growing season. The two nurseries were about $1 \mathrm{~km}$ away and surrounded by kiwifruit orchards. The nurseries were planted on 10 October 2012. In each nursery, seed of each wheat accession were planted in two rows of $100 \mathrm{~cm}$ in length, with a $10-\mathrm{cm}$ space between the two rows and a $25-\mathrm{cm}$ space between accessions for convenience of collecting rust data. Accessions in each nursery were arranged in a randomized block design with two replications. 'Xiaoyan 22', a local susceptible cultivar, was planted, also in two rows, between every 20 accessions as a susceptible check, and Mingxian 169 was planted at both ends of the nursery as a spreader. When flag leaves emerged, the nurseries were inoculated by spraying a mineral oil suspension of mixed urediniospores of the selected races on 10 April 2013. Nursery A was inoculated with Yr26-avirulent but predominant races CYR33, CYR32, and Su11-4, and nursery B was inoculated with these three races plus $Y r 26$-virulent race V26/Gui22. IT and disease severity (DS) were scored three times, at weekly interval, starting when the susceptible check had at least $30 \%$ severity using the modified Cobb scale (24). DS was assessed visually using the percentage of diseased leaf area. Both IT and DS on the third assessment that gave the highest DS were used to determine resistance or susceptibility of the accessions. For each entry, one-way analysis of variance (ANOVA) was performed with two replicates to estimate environmental effects.

DNA marker analysis. Sequence-tagged site (STS) markers WE173 and $B Q 74$, which are codominant markers and about 1.4 and 0.43 centimorgans flanking the $Y r 26$ locus $(33,40)$, were used to determine the presence or absence of $Y r 26$ in each wheat accession. DNA was extracted from leaves using the cetyltrimethyl ammonium bromide procedure (27). Polymerase chain reaction (PCR) reactions were performed in a S1000 Thermal Cycler (Bio-Rad Laboratories, Hercules, CA, USA)



Fig. 1. Location of the Sichuan Basin (shadowed) in China. Area 1: the most important oversummering area of Puccinia striiformis f. tritici and the major source of inoculum for wheat infection in autumn; area 2: the overwintering and reproducing region and the major spring inoculum source of $P$. striiformis f. tritici; and area 3: spring epidemic zones. 
in a $15-\mu \mathrm{l}$ volume, containing $1.0 \mathrm{U}$ of Taq DNA polymerase (Themo Fisher Scientific, Inc., Waltham, MA), $1.5 \mu$ l of $10 \times$ buffer $(50 \mathrm{mmol}$ $\mathrm{KCl}$ and $10 \mathrm{mmol}$ Tris- $\mathrm{HCl}), 1.2 \mathrm{mmol} \mathrm{MgCl}_{2}, 200 \mu \mathrm{mol}$ each dNTP, 6 pmol each primer, and 50 to $100 \mathrm{ng}$ of template DNA. The PCR condition was as follows: predenature at $94^{\circ} \mathrm{C}$ for $4 \mathrm{~min}$; followed by 35 cycles of $94^{\circ} \mathrm{C}$ for $1 \mathrm{~min}, 55^{\circ} \mathrm{C}$ for $1 \mathrm{~min}$, and $72^{\circ} \mathrm{C}$ for $1 \mathrm{~min}$; and a final extension for $10 \mathrm{~min}$ at $72^{\circ} \mathrm{C}$. PCR products were separated in $6 \%$ denature polyacrylamide gels. 92R137 and AvS were used as positive and negative controls, respectively.

\section{Results}

Virulence or avirulence patterns of the $P$. striiformis f. tritici races. The ITs of the five $P$. striiformis f. tritici races produced on the $Y r$ gene lines are shown in Table 2. The predominant races Su11-4, CYR32, and CYR33 were all avirulent to the $\mathrm{Yr} 26$ single-gene lines. In contrast, V26/CM42 and V26/Gui22 were virulent to the $Y r 26$ lines. The initial $Y r 26$-virulent race, V26/CM42, was virulent to $\operatorname{Yr} 6, \operatorname{Yr} 7, \operatorname{Yr} 8, \operatorname{Yr} 10, \operatorname{Yr} 17, \operatorname{Yr} 28, \operatorname{Yr} 29, \operatorname{YrTr} 1$, and $Y r 26$ but avirulent to $Y r 1, Y r 5, Y r 9, Y r 15, Y r 27, Y r 32$, and $\operatorname{YrSP}$. The later

Table 1. Pedigree and year of release of wheat cultivars and breeding lines from the Sichuan Basin used in this study

\begin{tabular}{|c|c|c|c|c|c|c|c|}
\hline \multicolumn{4}{|c|}{ Da } & & & & \\
\hline Number & Accession & Pedigree $^{\mathbf{a}}$ & $\begin{array}{l}\text { Year of } \\
\text { release }^{b}\end{array}$ & Number & Accession & Pedigree $^{a}$ & $\begin{array}{l}\text { Year of } \\
\text { release }^{b}\end{array}$ \\
\hline 1 & Mianyang 19 & Pedigree selection from Mianyang11 & 1984 & 41 & Xikemai 2 & Chuanyu11/Mo444 & 2005 \\
\hline 2 & Chuanmai 24 & $8282-15 \times$ Mianyang 19 & 1995 & 42 & Chuannong 26 & Chuannong19/R3301 & 2006 \\
\hline \multirow[t]{2}{*}{3} & \multirow[t]{2}{*}{ Chuanmai 28} & \multirow{2}{*}{$\begin{array}{l}\text { Wanya2/2874//Gaojiasuo/2874//I } \\
\text { Mianyang } 19\end{array}$} & \multirow[t]{2}{*}{1997} & 43 & Chuanyu 20 & SW3243//35050/21530 & 2006 \\
\hline & & & & 44 & Mianmai 41 & Mianyang01821/90-165//Guinong19-4 & 2006 \\
\hline 4 & Mianyang 26 & Mianyang20/Chuanyu 9 & 1998 & 45 & Mianmai 42 & Mianyang96-5/Guinong $\overline{21-1}$ & 2006 \\
\hline 5 & Chuanmai 30 & $\begin{array}{l}\text { 77/YAA//ALD‘S’/3/YSZ//ST2022/ } \\
983\end{array}$ & 1999 & 46 & Mianmai 43 & $\begin{array}{l}\text { 07146-12-1(Mianyang92-8/88-304)/ } \\
\text { Guinong19-4 }\end{array}$ & 2006 \\
\hline 6 & Chuanmai 32 & $(1900 ”$ S"Ning8439) $\times 1900$ & 2001 & 47 & Zimai 1 & Mianyang29/Chuanmai25 & 2006 \\
\hline 7 & Chuannong 10 & 78-5038/85-D.H.5015 & 2001 & 48 & Chengdianmai & MY92-8 / 91S-5-4 & 2007 \\
\hline 8 & Chuannong 11 & 78-5038/85-D.H.5015 & 2001 & 49 & Chuannong 24 & Baili3/Yunfan52894-2 & 2007 \\
\hline 9 & Chuanmai 35 & SW1862/2469 & 2002 & 50 & Chuannong 25 & $96 \mathrm{I}-225 \times 91 \mathrm{~S}-5-4$ & 2007 \\
\hline 10 & Chuanmai 36 & Milan/SW5193 & 2002 & 51 & Chuanyu 21 & Zhou88114/G159 & 2007 \\
\hline 11 & Chuannong 12 & 91S-23/A302 & 2002 & 52 & Liangmai 4 & N1491/N1071 & 2007 \\
\hline 12 & Chuannong 17 & $91 \mathrm{~S}-23 \times \mathrm{A} 302$ & 2002 & 53 & Mianmai 1403 & Mianyang04854/Guinong21-1 & 2007 \\
\hline 13 & Chuanyu 16 & 30020/8619-10//Jinmai30 & 2002 & 54 & Mianmai 45 & $07146-12-1 /$ Guinong19-4 & 2007 \\
\hline 14 & Chuanyu 17 & Mianyang26/G295-4 & 2002 & 55 & Neimai 11 & Pin $5 \times 94-7$ & 2007 \\
\hline 15 & Mianyang 31 & 90-310 × Chuanzhi89-076 & 2002 & 56 & Rongmai 4 & $96-2547 / 133-3$ & 2007 \\
\hline 16 & Chuanmai 38 & SynCD769/SW89-3243//Chuan6415 & 2003 & 57 & Xikemai 3 & Guinong21/5575 & 2007 \\
\hline 17 & Chuanmai 39 & $\overline{\text { Mo444/90-7 }}$ & 2003 & 58 & Chuanmai 51 & $\overline{174 / 183 / / 99}-1572$ & 2008 \\
\hline 18 & Chuanmai 41 & $91 \mathrm{~T} 4135 \times 88$ Fan 8 & 2003 & 59 & Chuanmai 52 & Chuanmai36/SW1862 & 2008 \\
\hline 19 & Chuanmai 42 & SynCD768/SW89-3243//Chuan6415 & 2003 & 60 & Mianmai 185 & Mianyang96-5/Liaochun10 & 2008 \\
\hline 20 & Chuannong 18 & Chuanyu $12 \times 87-429$ & 2003 & 61 & Mianmai 46 & $\overline{07242-3-1-1 / \text { Guinong21 }}$ & 2008 \\
\hline 21 & Chuannong 19 & Qian1104A/R935 & 2003 & 62 & Neimai 836 & $5680 / 92 \mathrm{R} 133$ & 2008 \\
\hline 22 & Chuanyu 18 & Chuanyu5/Mo460//94F2-4 & 2003 & 63 & Xikemai 4 & Mo460/9601-3 & 2008 \\
\hline 23 & Chuanyu 19 & Chuanyu5/Mo460//Mianyang26 & 2003 & 64 & Xikemai 6 & Mianyang95-325/92R-135 & 2008 \\
\hline 24 & Neimai 8 & Mianyang26/92R178 & 2003 & 65 & Chuannong 27 & chuannong19/R3301 & 2009 \\
\hline 25 & Xikemai 1 & Mianyang25/MoM-212 & 2003 & 66 & Mianmai 48 & Mianyang01821/Guinong19-4 & 2009 \\
\hline 26 & Chuanmai 43 & SynCD768/SW89-3243//chuan6415 & 2004 & 67 & Mianmai 367 & Mianyang $1275-1 / 99-1522$ & 2010 \\
\hline 27 & Chuanmai 44 & $96-440 /$ Guinong21 & 2004 & 68 & Chuanmai 60 & 98-1231//Guinong21/Shenghe3295 & 2011 \\
\hline 28 & Chuannong 21 & R843/Qianhui3 & 2004 & 69 & Chuanmai 104 & Chuanmai42/Chuannong16 & 2013 \\
\hline 29 & Liangmai 2 & Mianyang26/Yiyuan2 & 2004 & 70 & Mianmai 51 & $\overline{\text { Mian1275-1/99-1522 }}$ & 2013 \\
\hline 30 & Mianmai 37 & 96EW37/Mianyang90-100 & 2004 & 71 & Chuan 00030 & $\overline{88 \text { Fan8/88-309 }}$ & NR \\
\hline 31 & Mianmai 38 & 07146-12-1/Guinong19-4 & 2004 & 72 & LTM 18 & Unknown & NR \\
\hline 32 & Neimai 9 & Mianyang26/92R178 & 2004 & 73 & M9876 & Unknown & NR \\
\hline 33 & Xingmai2 & Mianyang26/92R178 & 2004 & 74 & Mian 05-164 & Unknown & NR \\
\hline 34 & Chuanmai 45 & GH430/SW1862 & 2005 & 75 & Mian 06-374 & Unknown & NR \\
\hline 35 & Chuanmai 46 & Ta193-6280/96-5429 & 2005 & 76 & Mian 1971-98 & Unknown & NR \\
\hline \multirow[t]{2}{*}{36} & \multirow[t]{2}{*}{ Chuanmai 47} & Syn-CD786/Mianyang26// & \multirow[t]{2}{*}{2005} & 77 & Mian11-13 & Unknown & NR \\
\hline & & Mianyang26 & & 78 & Mian11-25 & Unknown & NR \\
\hline 37 & Chuannong 22 & $\mathrm{R} 164 / 86-104$ & 2005 & 79 & Mian11-48 & Unknown & NR \\
\hline 38 & Chuannong 23 & R1658/MY26 & 2005 & 80 & Mianyang 96-5 & Unknown & NR \\
\hline 39 & Mianmai 39 & Mianyang96-78/Guinong21-1 & 2005 & 81 & MR 125 & Unknown & NR \\
\hline \multirow[t]{2}{*}{40} & Mianmai 40 & Mianyang01821/ $\overline{\text { Guinong19-4 }}$ & 2005 & 82 & MR 168 & Unknown & NR \\
\hline & \multicolumn{3}{|c|}{ (continued on next column) } & 83 & MR 71 & Unknown & NR \\
\hline & & & & $\begin{array}{l}84 \\
85\end{array}$ & $\begin{array}{l}\text { MR11-12 } \\
\text { MR11-20 }\end{array}$ & $\begin{array}{l}\text { Unknown } \\
\text { Unknown }\end{array}$ & $\begin{array}{l}\text { NR } \\
\text { NR }\end{array}$ \\
\hline
\end{tabular}

Yr26-virulent race, V26/Gui22, had a broader virulence spectrum, because it was virulent to $\operatorname{Yrl}, \operatorname{Yr} 6, \operatorname{Yr} 7, \operatorname{Yr} 8, \operatorname{Yr} 9, \operatorname{Yr} 10, \operatorname{Yr} 17$, $Y r 26, Y r 27, Y r 28, Y r 29$, and $Y r S P$ but avirulent to $Y r 5, Y r 15, Y r 32$, and $Y r T r 1$. These results indicate that the $Y r 26$ virulent population has evolved into more complex races. The results also indicate that $Y r 1, Y r 6, Y r 7, Y r 8, Y r 9, Y r 10, Y r 17, Y r T r 1$, and $Y r 26$ were not effective against the most predominant and emerging $Y r 26$-virulent races.

Evaluation of wheat cultivars and lines for reaction to $P$. striiformis f. tritici races. In seedling tests conducted in the greenhouse, of the 85 accessions, only $5(5.9 \%)$ were resistant and 19 $(22.3 \%)$ were susceptible to all four races tested, while the remaining $61(71.8 \%)$ were susceptible (or resistant) to one, two, or three races (Table 3). The frequency of susceptible accessions was $34.1 \%$ for race Su11-4, 36.6\% for CYR33, 48.2\% for CYR32, and 76.5\% for V26/Gui22. The $Y r 26$-virulent race V26/Gui22 made the majority of wheat accessions susceptible, including 50 (71.4\%) cultivars and $15(100 \%)$ breeding lines.

In the field trials, the analysis results by ANOVA for IT and DS of each entry showed that there were no significant differences between
Table 1. (continued from preceding column) 
replications in the same nursery, but obvious differences in reactions and significant differences in severity were detected for many accessions between the nurseries inoculated with races including or not including a Yr26-virulent race (V26/Gui22). Therefore, the final reactions and severity averaged between the two replications were presented and used to characterize the accessions (Table 3). In nursery A, inoculated with the three most predominant but $Y r 26$-avirulent races (CYR33, CYR32, and Su11-4), 58 (68.2\%) were resistant and 27 $(31.8 \%)$ were susceptible. In nursery B, which was inoculated with the three predominant races plus $Y r 26$-virulent race V26/Gui22, the number of susceptible accessions was increased by 25 , reaching 52 (61.2\%). All of the 25 cultivars changing from resistant to susceptible were found to have $Y r 26$ based on their pedigrees, greenhouse individual race tests, and the presence of the $Y r 26$ markers, as indicated below.

Presence and absence of $\mathbf{Y r 2 6}$ in wheat cultivars and lines. When the 85 accessions were tested with molecular markers $W E 173$ and $Q B-74$ for $Y r 26,33$ had both markers and, therefore, were considered to have $\operatorname{Yr} 26$ (Table 3). The molecular results were in consistent with the results based on the phenotypic IT data, except accessions 18 ('Chuanmai 41') and 68 ('Chuanmi 60') that did not have the marker alleles of 92R137.

\section{Discussion}

The emerging $Y r 26$-virulent races, such as V26/CM42 and V26/ Gui22, have overcome $\operatorname{Yr} 26(=\operatorname{Yr} 24)$ and $Y r 10$, which are effective against all previously identified $P$. striiformis $\mathrm{f}$. tritici races and have been deployed in commercial cultivars to fight predominant races of the fungus in China. Race V26/CM42, detected in 2008, was found to be virulent to these genes. The present study confirmed the $Y r 26$ virulence and proved it as a race different from the predominant races CYR32, CYR33, and Su11-4. Race V26/Gui22, collected in 2012, is an even more virulent race than V26/CM42 because it has a broader virulence spectrum than V26/CM42. This race is a bigger threat to wheat production in the Sichuan Basin. It is noteworthy that all 33 Yr26 wheat accessions were resistant in nursery A, whereas 24 of them became susceptible in nursery B and only 9 of them showed resistance to all four races used in the inoculation. These results, together with the seedling data from the greenhouse, indicated that the $\mathrm{Yr} 26$-virulent race was virulent to $\mathrm{Yr} 26$ at both seedling and adult plant stages. The high numbers of susceptible accessions in the greenhouse and fields indicate that the predominant races continue posing threats and the emerging $Y r 26$-virulent races pose an even greater threat to breeding programs and production of wheat in the Sichuan Basin.
More than $76 \%$ of wheat cultivars and breeding lines from the Sichuan Basin are susceptible to the Yr26-virulent races at the seedling stage. The emerging races could be a threat to other wheatgrowing areas because $P$. striiformis f. tritici can spread from the Sichuan Basin to the east $(5,12,15)$, although wheat cultivars grown in other regions were not tested in the present study. Wheat entries from many regions have been tested in the field in the Sichuan Basin but the relatively low frequencies of the $Y r 26$ virulence thus far may not provide adequate information. Therefore, further testing of cultivars and breeding lines from other regions with $\mathrm{Yr} 26$-virulent races under controlled conditions is needed.

In the late 1990s, Yr26 was introduced into Sichuan wheat breeding programs as the 92R series lines (92R133, 92R137, 92R149, and 92R178) and Guinong series lines (Guinong 19, Guinong 21, and Guinong 22). Neimai 8 (Mianyang 26/92R178) was released in 2003 as the first cultivar with $Y r 26$. Yr24, derived from T. turgidum var. durum accession K733, was introduced into Sichuan wheat breeding programs by a synthetic wheat resistance line Syn769 (AABBDD), which was developed from Decoy 1 (T. turgidum accession AABB) crossed with Aegilops tauschii 188 (DD) (16). Chuanmai 42, also released in 2003, was the first Chinese cultivar with $Y r 24$. Since then, more than 30 wheat cultivars and breeding lines have been developed that have Yr26 or Yr24 (Table 1). Previous studies suggested that $Y r 24, \operatorname{Yr} 26$, and $\mathrm{YrCH} 42$ should be the same gene $(11,16,22)$. In the present study, the $Y r 24$ and $Y r 26$ near-isogenic lines Guinong 22, 92R137, and Chuanmai 42 were all resistant to the $Y r 26$-avirulent races and susceptible to the $Y r 26$-virulent races, supporting the idea that $Y r 24$ and $Y r 26$ are the same gene. Because of the high potential yields and high resistance to predominant races CYR32 and CYR33, cultivars with $Y r 26$ such as Chuanmai 42, Neimai 8, and Mianmai 37 have become the major cultivars grown in the Sichuan Basin in recent years. Unfortunately, these cultivars are susceptible to the emerging $Y r 26$-virulent races, and should be withdrawn from production as soon as possible to avoid devastating epidemics.

It is interesting that the $Y r 26$-virulent races are also virulent to $\mathrm{Yr} 10$. However, $\mathrm{Yr} 10$ is a gene different from $\mathrm{Yr} 26$ and $\mathrm{Yr} 24$, as demonstrated by previous studies with virulence data and molecular markers $(11,29,31)$. The present study shows that $\operatorname{Yr} 10$ is no longer effective against the $P$. striiformis $\mathrm{f}$. tritici population in China. $\mathrm{Yr} 10$ has not been used as much as $Y r 26$ in wheat breeding programs in China. However, cultivars with $\mathrm{Yr} 10$ are also at risk. Although we did not attempt to determine wheat cultivars and breeding lines for the presence of $\operatorname{YrlO}$ in the present study, Chuanmai 41 and

Table 2. Infection types of Puccinia striiformis f. tritici races used in the study based on $17 \mathrm{Yr}$ single-gene lines and $3 \mathrm{Yr} 26$ (=Yr24) donor lines

\begin{tabular}{|c|c|c|c|c|c|c|c|}
\hline \multirow[b]{2}{*}{ Number } & \multirow[b]{2}{*}{ Line } & \multirow[b]{2}{*}{$Y r$ genes } & \multicolumn{5}{|c|}{ Infection type } \\
\hline & & & Su11-4 & CYR32 & CYR33 & CM42 & Gui22 \\
\hline 1 & AvSYr1NIL & $Y r 1$ & 7 & 9 & 8 & 1 & 9 \\
\hline 2 & AvSYr5NIL & $\operatorname{Yr} 5$ & 0 & 1 & 0 & 0 & 1 \\
\hline 3 & AvSYr6NIL & $\operatorname{Yr} 6$ & 8 & 9 & 9 & 9 & 9 \\
\hline 4 & AvSYr7NIL & $Y r 7$ & 9 & 9 & 7 & 9 & 9 \\
\hline 5 & AvSYr8NIL & $\operatorname{Yr} 8$ & 8 & 9 & 0 & 9 & 7 \\
\hline 6 & AvSYr9NIL & $\operatorname{Yr} 9$ & 8 & 9 & 8 & 1 & 9 \\
\hline 7 & AvSYr10NIL & Yr10 & 0 & 2 & 2 & 7 & 8 \\
\hline 8 & AvSYr15NIL & $\operatorname{Yr} 15$ & 0 & 0 & 0 & 0 & 0 \\
\hline 9 & AvSYr17NIL & $\operatorname{Yr} 17$ & 5 & 9 & 8 & 8 & 8 \\
\hline 10 & AvSYr24NIL & $\operatorname{Yr} 24$ & 1 & 0 & 2 & 7 & 9 \\
\hline 11 & AvSYr26NIL & $\operatorname{Yr} 26$ & 1 & 2 & 2 & 9 & 9 \\
\hline 12 & AvSYr27NIL & $\operatorname{Yr} 27$ & 5 & 9 & 3 & 6 & 9 \\
\hline 13 & AvSYr28NIL & $\operatorname{Yr} 28$ & 9 & 9 & 9 & 7 & 9 \\
\hline 14 & AvSYr29NIL & $\operatorname{Yr} 29$ & 9 & 9 & 9 & 8 & 9 \\
\hline 15 & AvSYr32NIL & $\operatorname{Yr} 32$ & 2 & 2 & 2 & 4 & 4 \\
\hline 16 & AvSYrSPNIL & $Y r S P$ & 6 & 9 & 9 & 2 & 9 \\
\hline 17 & AvSYrTr1NIL & $\operatorname{YrTr} 1$ & 1 & 2 & 2 & 9 & 2 \\
\hline 18 & Avocet S (AvS) & Unknown & 9 & 9 & 9 & 9 & 9 \\
\hline 19 & Chuanmai 42 & $Y r 24$ & 1 & 2 & 2 & 8 & 9 \\
\hline 20 & Guinong 22 & $\operatorname{Yr} 26$ & 1 & 2 & 2 & 7 & 9 \\
\hline 21 & 92R137 & $\operatorname{Yr} 26$ & 1 & 2 & 1 & 7 & 9 \\
\hline
\end{tabular}


Chuanmai 60, which were resistant to the $Y r 26$-avirulent races and susceptible to the $\operatorname{Yr} 26$-virulent races, may have $\operatorname{Yr} 10$ because they do not have $\operatorname{Yr26}$. The hypothesis can be tested with molecular markers or with races that can differentiate $\mathrm{YrlO}$ and $\mathrm{Yr} 26$ from other countries. The presence of $\mathrm{YrlO}$ in wheat cultivars in other regions of China also needs to be studied.

The Sichuan Basin is considered a secondary center for emerging new $P$. striiformis f. tritici races and stripe rust epidemics in China $(12,17,39)$. The appearance and development of the $\mathrm{Yr} 26$-virulent races support this point, although it is still not clear where the $Y r 26$ virulence originated. More wheat cultivars and breeding lines with $\mathrm{Yr} 26$ in the Sichuan Basin than any other region apparently selected the $Y r 26$ virulence. The Sichuan Basin wheat region is adjacent to the pathogen oversummering areas. In the autumn, $P$. striiformis f. tritici inocula from southern Gansu, northwestern Sichuan, and other areas in the southwestern region could be blown by wind to the Sichuan Basin, where the pathogen can infect, reproduce, and spread to the regions further east and north. Similarly, urediniospores produced in the basin may be spread back to infect wheat crops in the oversummering regions. The shuttling of $P$. striiformis f. tritici between the oversummering and overwintering regions can spread to other regions, which makes the Yr26-virulent races a great concern for the whole country.

Using pedigrees, phenotype data, and molecular markers, we were able to detect $Y r 26$ in wheat cultivars and breeding lines in the present study. The molecular markers apparently provide accurate information about the presence and absence of the gene. Such accurate

Table 3. Seedling infection types (ITs), severity, and reactions at adult-plant stage in the field nurseries, molecular markers detected, and presence (P) or absence (A) of $\operatorname{Yr} 26$ in the 85 wheat accessions

\begin{tabular}{|c|c|c|c|c|c|c|c|c|c|c|c|}
\hline \multirow[b]{2}{*}{ Number } & \multirow[b]{2}{*}{ Accession } & \multicolumn{4}{|c|}{ Seedling IT ${ }^{\mathbf{a}}$} & \multicolumn{3}{|c|}{ Adult-plant severity and reaction ${ }^{b}$} & \multicolumn{2}{|c|}{$\begin{array}{c}\text { Molecular } \\
\text { markers }\end{array}$} & \multirow[b]{2}{*}{$\operatorname{Yr26}$} \\
\hline & & CYR32 & CYR33 & Su11-4 & Gui22 & Nursery $A^{d}$ & Nursery $B^{e}$ & Type & WE173 & QB-74 & \\
\hline 1 & Mianyang 19 & 9 & 8 & 7 & 8 & $100 \mathrm{~S}$ & $100 \mathrm{~S}$ & $\mathrm{~S}$ & - & - & $\mathrm{N}$ \\
\hline 2 & Chuanmai 24 & 8 & 9 & 9 & 8 & $30 \mathrm{~S}$ & $80 \mathrm{~S}$ & $\mathrm{~S}$ & - & - & $\mathrm{N}$ \\
\hline 3 & Chuanmai 28 & 3 & 9 & 9 & 7 & $60 \mathrm{~S}$ & $80 \mathrm{~S}$ & $\mathrm{~S}$ & - & - & $\mathrm{N}$ \\
\hline 4 & Mianyang 26 & 9 & 5 & 8 & 7 & $30 \mathrm{~S}$ & $60 \mathrm{~S}$ & $\mathrm{~S}$ & - & - & $\mathrm{N}$ \\
\hline 5 & Chuanmai 30 & 9 & 5 & 7 & 5 & $60 \mathrm{~S}$ & $80 \mathrm{~S}$ & $\mathrm{~S}$ & - & - & $\mathrm{N}$ \\
\hline 6 & Chuanmai 32 & 9 & 8 & 9 & 7 & $30 \mathrm{~S}$ & $60 \mathrm{~S}$ & S & - & - & $\mathrm{N}$ \\
\hline 7 & Chuannong 10 & 7 & 7 & 7 & 3 & $30 \mathrm{~S}$ & $30 \mathrm{~S}$ & $\mathrm{~S}$ & - & - & $\mathrm{N}$ \\
\hline 8 & Chuannong 11 & 7 & 7 & 5 & 3 & $30 \mathrm{~S}$ & $30 \mathrm{~S}$ & $\mathrm{~S}$ & - & - & $\mathrm{N}$ \\
\hline 9 & Chuanmai 35 & 1 & 1 & 7 & 1 & $10 \mathrm{R}$ & $30 \mathrm{MR}$ & APR & - & - & $\mathrm{N}$ \\
\hline 10 & Chuanmai 36 & 8 & 5 & 5 & 8 & $40 \mathrm{~S}$ & $60 \mathrm{~S}$ & $\mathrm{~S}$ & + & - & $\mathrm{N}$ \\
\hline 11 & Chuannong 12 & 5 & 1 & 1 & 1 & $30 \mathrm{MR}$ & $20 \mathrm{MR}$ & ASR & - & - & $\mathrm{N}$ \\
\hline 12 & Chuannong 17 & 7 & 1 & 1 & 1 & $5 \mathrm{R}$ & $10 \mathrm{MR}$ & APR & - & - & $\mathrm{N}$ \\
\hline 13 & Chuanyu 16 & 8 & 1 & 1 & 1 & $10 \mathrm{R}$ & $30 \mathrm{R}$ & APR & - & - & $\mathrm{N}$ \\
\hline 14 & Chuanyu 17 & 9 & 7 & 1 & 7 & $1 \mathrm{R}$ & $1 \mathrm{R}$ & APR & - & - & $\mathrm{N}$ \\
\hline 15 & Mianyang 31 & 9 & 9 & 7 & 7 & $30 \mathrm{~S}$ & $30 \mathrm{~S}$ & $S$ & - & - & $\mathrm{N}$ \\
\hline 16 & Chuanmai 38 & 8 & 8 & 5 & 7 & $10 \mathrm{MR}$ & $60 \mathrm{~S}$ & $\mathrm{~S}$ & + & - & $\mathrm{N}$ \\
\hline 17 & Chuanmai 39 & 1 & 9 & 7 & 7 & $20 \mathrm{~S}$ & $30 \mathrm{~S}$ & $\mathrm{~S}$ & - & - & $\mathrm{N}$ \\
\hline 18 & Chuanmai 41 & 1 & 1 & 5 & 7 & $30 \mathrm{MR}$ & $30 \mathrm{R}$ & APR & - & - & $\mathrm{N}$ \\
\hline 19 & Chuanmai 42 & 3 & 1 & 3 & 9 & $1 \mathrm{R}$ & $60 \mathrm{~S}$ & $\mathrm{~S}$ & + & + & $\mathrm{Y}$ \\
\hline 20 & Chuannong 18 & 3 & 1 & 1 & 5 & $10 \mathrm{R}$ & $10 \mathrm{MR}$ & ASR & - & - & $\mathrm{N}$ \\
\hline 21 & Chuannong 19 & 9 & 7 & 5 & 1 & $1 \mathrm{R}$ & $1 \mathrm{R}$ & APR & - & - & $\mathrm{N}$ \\
\hline 22 & Chuanyu 18 & 9 & 9 & 7 & 7 & $30 \mathrm{~S}$ & $60 \mathrm{~S}$ & $\mathrm{~S}$ & - & - & $\mathrm{N}$ \\
\hline 23 & Chuanyu 19 & 9 & 9 & 7 & 7 & $60 \mathrm{~S}$ & $60 \mathrm{~S}$ & $\mathrm{~S}$ & - & - & $\mathrm{N}$ \\
\hline 24 & Neimai 8 & 1 & 1 & 1 & 7 & $1 \mathrm{R}$ & $30 \mathrm{~S}$ & S & + & + & $\mathrm{Y}$ \\
\hline 25 & Xikemai 1 & 9 & 9 & 7 & 9 & $100 \mathrm{~S}$ & $100 \mathrm{~S}$ & $\mathrm{~S}$ & - & - & $\mathrm{N}$ \\
\hline 26 & Chuanmai 43 & 1 & 1 & 5 & 7 & $1 \mathrm{R}$ & $80 \mathrm{~S}$ & $\mathrm{~S}$ & + & + & $\mathrm{Y}$ \\
\hline 27 & Chuanmai 44 & 1 & 1 & 1 & 7 & $1 \mathrm{R}$ & $1 \mathrm{R}$ & APR & + & + & $\mathrm{Y}+?$ \\
\hline 28 & Chuannong 21 & 7 & 9 & 7 & 7 & $30 \mathrm{~S}$ & $80 \mathrm{~S}$ & $\mathrm{~S}$ & - & - & $\mathrm{N}$ \\
\hline 29 & Liangmai 2 & 7 & 7 & 7 & 9 & $60 \mathrm{~S}$ & $80 \mathrm{~S}$ & S & - & - & $\mathrm{N}$ \\
\hline 30 & Mianmai 37 & 1 & 5 & 1 & 7 & $1 \mathrm{R}$ & $30 \mathrm{~S}$ & $\mathrm{~S}$ & + & + & $\mathrm{Y}$ \\
\hline 31 & Mianmai 38 & 5 & 9 & 1 & 1 & $5 \mathrm{R}$ & $10 \mathrm{R}$ & APR & - & - & $\mathrm{N}$ \\
\hline 32 & Neimai 9 & 1 & 1 & 5 & 7 & $1 \mathrm{R}$ & $30 \mathrm{~S}$ & $\mathrm{~S}$ & + & + & $\mathrm{Y}$ \\
\hline 33 & Xingmai 2 & 1 & 1 & 5 & 7 & $1 \mathrm{R}$ & $80 \mathrm{~S}$ & $\mathrm{~S}$ & + & + & $\mathrm{Y}$ \\
\hline 34 & Chuanmai 45 & 9 & 5 & 5 & 1 & $1 \mathrm{R}$ & $1 \mathrm{R}$ & APR & - & - & $\mathrm{N}$ \\
\hline 35 & Chuanmai 46 & 1 & 1 & 1 & 3 & $10 \mathrm{MR}$ & $10 \mathrm{MR}$ & ASR & - & - & $\mathrm{N}$ \\
\hline 36 & Chuanmai 47 & 3 & 1 & 5 & 7 & $5 \mathrm{R}$ & $10 \mathrm{R}$ & APR & + & + & $\mathrm{Y}+?$ \\
\hline 37 & Chuannong 22 & 5 & 1 & 5 & 9 & $1 \mathrm{R}$ & $30 \mathrm{~S}$ & $\mathrm{~S}$ & + & + & $\mathrm{Y}$ \\
\hline 38 & Chuannong 23 & 5 & 1 & 1 & 7 & $1 \mathrm{R}$ & $30 \mathrm{~S}$ & $\mathrm{~S}$ & + & + & $\mathrm{Y}$ \\
\hline \multirow[t]{2}{*}{39} & Mianmai 39 & 1 & 1 & 1 & 7 & $1 \mathrm{R}$ & $80 \mathrm{~S}$ & $\mathrm{~S}$ & + & + & $\mathrm{Y}$ \\
\hline & & & & & & & & & \multicolumn{3}{|c|}{ (continued on next page) } \\
\hline
\end{tabular}

a Seedling ITs were based on the 0-to-9 scale (18), where ITs 0 to 6 are considered resistant and ITs 7 to 9 susceptible.

b A field response was a combination of disease severity recorded as a single value for each accession at each site from 0 to $100 \%$ of the foliage infected using the modified Cobb scale (24), where $\mathrm{R}=$ resistant, $\mathrm{MR}=$ moderately resistant, $\mathrm{M}=$ moderately resistant to moderately susceptible, $\mathrm{MS}=$ moderately susceptible, and $\mathrm{S}=$ susceptible, $\mathrm{APR}=$ adult plant resistance, $\mathrm{ASR}=$ all stage resistance.

c Symbols + and - indicate presence and absence, respectively, of the Sequence-tagged site markers.

d Nursery A was inoculated with a mixture of three races (CYR32, CYR33, and Su11-4) that are all avirulent to Yr26.

e Nursery B was inoculated with a mixture of races CYR32, CYR33, Su11-4, and a Yr26-virulent race, Gui22.

f Symbol + ? indicates the presence of an unknown $\mathrm{Yr}$ gene or genes in addition to $\mathrm{Yr} 26$.

g Number of resistant accessions.

h Number of susceptible accessions.

i Number of accessions with $Y r 26$. 
marker-assisted detection has been achieved by a series of studies $(33,37,40)$. From these markers, we selected two STS markers (WE173 and BQ74) to detect the presence and absence of $Y r 26$ in the 85 wheat cultivars and breeding lines. In the results, we conclude that 31 accessions have $Y r 26$ and the markers, when used in combination, are more accurate than the phenotypic data for detection of $Y r 26$. Although $Y r 26$ is no longer effective against the new races, keeping the gene in new wheat cultivars together with other effective resistance genes still has value in protecting wheat crops against races avirulent to Yr26 but still predominant. The markers are helpful for detecting the presence of Yr26. However, breeding programs should use other effective resistance genes in combination and, even better, to combine with adult-plant resistance genes that are more likely to last longer. The use of a single gene conferring a high level of resistance, such as Yr26 in the past, should be avoided. In the present study, some of the wheat cultivars and breeding lines with $Y r 26$ showed various levels of adultplant resistance in the field tests, including 'Chuanmai 44', 'Chuanmai 47', 'Chuanmai 5', 'Neimai 11', 'Neimai 836', 'Mian 05-164', MR 71, MR 11-12, and MR 11-20. These cultivars and breeding lines could be continually grown or released if they have other required traits. However, further studies should be conducted under early and heavy infection of $Y r 26$-virulent races to determine whether they have adequate resistance, because adult-plant resistance is usually affected by growth stage, temperature, and inoculum load $(6,7,25)$.

Diligently monitoring stripe rust in the Sichuan Basin and other regions is needed to keep track of stripe rust occurrence and

Table 3. (continued from preceding page)

\begin{tabular}{|c|c|c|c|c|c|c|c|c|c|c|c|}
\hline \multirow[b]{2}{*}{ Number } & \multirow[b]{2}{*}{ Accession } & \multicolumn{4}{|c|}{ Seedling IT ${ }^{\mathbf{a}}$} & \multicolumn{3}{|c|}{ Adult-plant severity and reaction ${ }^{b}$} & \multicolumn{2}{|c|}{$\begin{array}{c}\text { Molecular } \\
\text { markers }^{c}\end{array}$} & \multirow[b]{2}{*}{$\operatorname{Yr26}^{\mathrm{I}}$} \\
\hline & & CYR32 & CYR33 & Su11-4 & Gui22 & Nursery $A^{d}$ & Nursery $B^{e}$ & $\overline{\text { Type }}$ & WE173 & QB-74 & \\
\hline 40 & Mianmai 40 & 9 & 7 & 9 & 7 & $10 \mathrm{R}$ & $30 \mathrm{R}$ & APR & - & - & $\mathrm{N}$ \\
\hline 41 & Xikemai 2 & 9 & 7 & 7 & 7 & $80 \mathrm{~S}$ & $80 \mathrm{~S}$ & S & - & - & $\mathrm{N}$ \\
\hline 42 & Chuannong 26 & 9 & 1 & 9 & 9 & $1 \mathrm{R}$ & $10 \mathrm{R}$ & APR & - & - & $\mathrm{N}$ \\
\hline 43 & Chuanyu 20 & 9 & 7 & 3 & 1 & $10 \mathrm{MR}$ & $20 \mathrm{MR}$ & APR & - & - & $\mathrm{N}$ \\
\hline 44 & Mianmai 41 & 7 & 7 & 3 & 3 & $10 \mathrm{MR}$ & $10 \mathrm{MR}$ & APR & - & - & $\mathrm{N}$ \\
\hline 45 & Mianmai 42 & 1 & 1 & 5 & 7 & $1 \mathrm{R}$ & $80 \mathrm{~S}$ & $\mathrm{~S}$ & + & + & $\mathrm{Y}$ \\
\hline 46 & Mianmai 43 & 5 & 5 & 1 & 1 & $1 \mathrm{R}$ & $1 \mathrm{R}$ & ASR & - & - & $\mathrm{N}$ \\
\hline 47 & Zimai 1 & 7 & 7 & 7 & 9 & $60 \mathrm{~s}$ & $80 \mathrm{~S}$ & $\mathrm{~S}$ & - & - & $\mathrm{N}$ \\
\hline 48 & Chengdianmai & 7 & 9 & 9 & 9 & $60 \mathrm{~S}$ & $60 \mathrm{~S}$ & S & - & - & $\mathrm{N}$ \\
\hline 49 & Chuannong 24 & 9 & 9 & 9 & 9 & $10 \mathrm{MR}$ & $20 \mathrm{MR}$ & APR & - & - & $\mathrm{N}$ \\
\hline 50 & Chuannong 25 & 7 & 1 & 5 & 9 & $30 \mathrm{~S}$ & $80 \mathrm{~S}$ & $\mathrm{~S}$ & - & - & $\mathrm{N}$ \\
\hline 51 & Chuanyu 21 & 7 & 1 & 1 & 1 & $1 \mathrm{R}$ & $1 \mathrm{R}$ & APR & - & - & $\mathrm{N}$ \\
\hline 52 & Liangmai 4 & 9 & 7 & 7 & 7 & $80 \mathrm{~S}$ & $100 \mathrm{~S}$ & $\mathrm{~S}$ & - & - & $\mathrm{N}$ \\
\hline 53 & Mianmai 1403 & 9 & 9 & 1 & 1 & $30 \mathrm{~S}$ & $30 \mathrm{~S}$ & S & - & - & $\mathrm{N}$ \\
\hline 54 & Mianmai 45 & 9 & 1 & 1 & 1 & $10 \mathrm{R}$ & $30 \mathrm{R}$ & APR & - & - & $\mathrm{N}$ \\
\hline 55 & Neimai 11 & 1 & 1 & 1 & 7 & $1 \mathrm{R}$ & $10 \mathrm{MR}$ & APR & + & + & $\mathrm{Y}+?$ \\
\hline 56 & Rongmai 4 & 1 & 1 & 1 & 7 & $1 \mathrm{R}$ & $60 \mathrm{~S}$ & $\mathrm{~S}$ & + & + & $\mathrm{Y}$ \\
\hline 57 & Xikemai 3 & 9 & 9 & 9 & 9 & $100 \mathrm{~S}$ & $100 \mathrm{~S}$ & S & - & - & $\mathrm{N}$ \\
\hline 58 & Chuanmai 51 & 1 & 1 & 1 & 7 & $30 \mathrm{MR}$ & $60 \mathrm{MR}$ & APR & + & + & $\mathrm{Y}+?$ \\
\hline 59 & Chuanmai 52 & 5 & 1 & 1 & 1 & $10 \mathrm{MR}$ & $10 \mathrm{MR}$ & ASR & - & - & $\mathrm{N}$ \\
\hline 60 & Mianmai 185 & 9 & 1 & 7 & 7 & $30 \mathrm{~S}$ & $60 \mathrm{~S}$ & $S$ & - & - & $\mathrm{N}$ \\
\hline 61 & Mianmai 46 & 9 & 1 & 5 & 7 & $5 \mathrm{R}$ & $10 \mathrm{R}$ & APR & - & - & $\mathrm{N}$ \\
\hline 62 & Neimai 836 & 1 & 1 & 1 & 7 & $1 \mathrm{R}$ & $10 \mathrm{MR}$ & APR & + & + & $\mathrm{Y}+?$ \\
\hline 63 & Xikemai 4 & 1 & 3 & 5 & 9 & $0 \mathrm{R}$ & $30 \mathrm{~S}$ & $\mathrm{~S}$ & + & + & $\mathrm{Y}$ \\
\hline 64 & Xikemai 6 & 1 & 3 & 3 & 9 & $0 \mathrm{R}$ & $40 \mathrm{~S}$ & S & + & + & $\mathrm{Y}$ \\
\hline 65 & Chuannong 27 & 9 & 1 & 7 & 1 & $5 \mathrm{MR}$ & $10 \mathrm{MR}$ & APR & - & - & $\mathrm{N}$ \\
\hline 66 & Mianmai 48 & 7 & 7 & 9 & 7 & $10 \mathrm{R}$ & $30 \mathrm{R}$ & APR & - & - & $\mathrm{N}$ \\
\hline 67 & Mianmai 367 & 1 & 1 & 5 & 9 & $1 \mathrm{R}$ & $80 \mathrm{~S}$ & $\mathrm{~S}$ & + & + & $\mathrm{Y}$ \\
\hline 68 & Chuanmai 60 & 1 & 1 & 5 & 7 & $10 \mathrm{R}$ & $20 \mathrm{R}$ & APR & - & - & $\mathrm{N}$ \\
\hline 69 & Chuanmai 104 & 3 & 1 & 5 & 9 & $1 \mathrm{R}$ & $40 \mathrm{~S}$ & $\mathrm{~S}$ & + & + & $\mathrm{Y}$ \\
\hline 70 & Mianmai 51 & 1 & 3 & 5 & 9 & $1 \mathrm{R}$ & $80 \mathrm{~S}$ & $S$ & + & + & $\mathrm{Y}$ \\
\hline 71 & Chuan 00030 & 9 & 7 & 7 & 9 & $80 \mathrm{~S}$ & $80 \mathrm{~S}$ & S & - & - & $\mathrm{N}$ \\
\hline 72 & LTM 18 & 9 & 7 & 9 & 7 & $80 \mathrm{~S}$ & $80 \mathrm{~S}$ & S & - & - & $\mathrm{N}$ \\
\hline 73 & M9876 & 9 & 9 & 9 & 9 & $60 \mathrm{~S}$ & $60 \mathrm{~S}$ & S & - & - & $\mathrm{N}$ \\
\hline 74 & Mian 05-164 & 1 & 1 & 1 & 7 & $1 \mathrm{R}$ & $30 \mathrm{MR}$ & APR & + & + & $\mathrm{Y}+?$ \\
\hline 75 & Mian 06-374 & 1 & 1 & 5 & 9 & $1 \mathrm{R}$ & $80 \mathrm{~S}$ & $\mathrm{~S}$ & + & + & $\mathrm{Y}$ \\
\hline 76 & Mian 1971-98 & 1 & 1 & 5 & 7 & $1 \mathrm{R}$ & $60 \mathrm{~S}$ & S & + & + & $\mathrm{Y}$ \\
\hline 77 & Mian11-13 & 3 & 3 & 0 & 7 & $0 \mathrm{R}$ & $20 \mathrm{~S}$ & S & + & + & $\mathrm{Y}$ \\
\hline 78 & Mian11-25 & 3 & 3 & 0 & 9 & $0 \mathrm{R}$ & $60 \mathrm{~S}$ & S & + & + & $\mathrm{Y}$ \\
\hline 79 & Mian11-48 & 1 & 3 & 0 & 7 & $0 \mathrm{R}$ & $30 \mathrm{~S}$ & S & + & + & $\mathrm{Y}$ \\
\hline 80 & Mianmai 96-5 & 1 & 1 & 1 & 7 & $1 \mathrm{R}$ & $30 \mathrm{~S}$ & S & + & + & $\mathrm{Y}$ \\
\hline 81 & MR 125 & 5 & 1 & 1 & 7 & $1 \mathrm{R}$ & $30 \mathrm{~S}$ & S & + & + & $\mathrm{Y}$ \\
\hline 82 & MR 168 & 1 & 1 & 1 & 7 & $1 \mathrm{R}$ & $80 \mathrm{~S}$ & $\mathrm{~S}$ & + & + & $\mathrm{Y}$ \\
\hline 83 & MR 71 & 5 & 1 & 1 & 7 & $1 \mathrm{R}$ & $10 \mathrm{MR}$ & APR & + & + & $\mathrm{Y}+?$ \\
\hline 84 & MR11-12 & 3 & 3 & 0 & 7 & $0 \mathrm{R}$ & $5 \mathrm{R}$ & APR & + & + & $\mathrm{Y}+$ ? \\
\hline 85 & MR11-20 & 1 & 3 & 0 & 7 & $0 \mathrm{R}$ & $5 \mathrm{R}$ & APR & + & + & $\mathrm{Y}+?$ \\
\hline CK1 & Avocet S & 9 & 9 & 9 & 9 & $100 \mathrm{~S}$ & $100 \mathrm{~S}$ & $\mathrm{~S}$ & - & - & $\mathrm{A}$ \\
\hline CK2 & 92R137 & 1 & 1 & 0 & 9 & $1 \mathrm{R}$ & $40 \mathrm{~S}$ & S & + & + & $\mathrm{P}$ \\
\hline Total $\mathrm{R}^{\mathrm{g}}$ & & 44 & 54 & 56 & 20 & 58 & 33 & $\ldots$ & $\ldots$ & $\ldots$ & $\ldots$ \\
\hline Total $\mathrm{S}^{\mathrm{h}}$ & & 41 & 31 & 29 & 65 & 27 & 52 & $\ldots$ & $\ldots$ & $\ldots$ & $\ldots$ \\
\hline Total $Y r 26^{\mathrm{i}}$ & & $\ldots$ & $\ldots$ & $\ldots$ & $\ldots$ & $\ldots$ & $\ldots$ & $\ldots$ & $\ldots$ & $\ldots$ & 20 \\
\hline
\end{tabular}


development, cultivar reaction changes, and race changes in frequency and distribution. Accurate forecasts of stripe rust epidemics could be made from the disease monitoring and weather conditions $(29,31)$. Whenever appropriate, fungicides can be used to prevent epidemics and reduce yield losses $(6,36)$. Ultimately, more effective resistance genes should be identified and used in breeding programs to develop wheat cultivars with diversified genes providing highlevel and durable resistance to stripe rust.

\section{Acknowledgments}

This study was financially supported by the National Basic Research Program of China (number 2013CB127700), the National High-Tech R\&D Program of China (number 2012AA101503), the earmarked fund for Modern Agro-industry Technology Research System (number CARS-3-1-11), the National Natural Science Foundation of China (31371924), and the 111 Project from the Ministry of Education of China (B07049).

\section{Literature Cited}

1. Brown, J. K. M., and Hovmøller, M. S. 2002. Aerial dispersal of pathogens on the global and continental scales and its impact on plant disease. Science 297: 537-541.

2. Burdon, J. J., Barrett, L. G., Rebetzke, G., and Thrall, P. H. 2014. Guiding deployment of resistance in cereals using evolutionary principles. Evol. Appl. 7:609-624.

3. Cao, A. Z., Xing, L. P., Wang, X. Y., Yang, X. M., Wang, W., Sun, Y. L., Qian, C., Ni, J. L., Chen, Y. P., Liu, D. J., Wang, X. E., and Chen, P. D. 2011. Serine/threonine kinase gene Stpk-V, a key member of powdery mildew resistance gene $P m 21$, confers powdery mildew resistance in wheat. Proc. Natl. Acad. Sci. USA 108:7727-7732.

4. Chen, P. D., Qi, L. L., and Zhou, B. 1995. Development and molecular cytogenetic analysis of wheat-Haynaldia villosa 6VS/6AL translocation lines specifying resistance to powdery mildew. Theor. Appl. Genet. 91:1125-1128.

5. Chen, W., Wellings, C., Chen, X. M., Kang, Z., and Liu, T. 2014. Wheat stripe (yellow) rust caused by Puccinia striiformis f. sp. tritici. Mol. Plant Pathol. 15: 433-446.

6. Chen, X. M. 2005. Epidemiology and control of stripe rust (Puccinia striiformis f. sp. tritici) on wheat. Can. J. Plant Pathol. 27:314-337.

7. Chen, X. M. 2013. Review article: High-temperature adult-plant resistance, key for sustainable control of stripe rust. Amer. J. Plant Sci. 4:608-627.

8. Chen, X. M., and Line, R. F. 1995. Gene action in wheat cultivars for durable, high-temperature, adult-plant resistance and interaction with race-specific, seedling resistance to Puccinia striiformis. Phytopathology 85:567-572.

9. Chen, X. M., and Line, R. F. 1995. Gene number and heritability of wheat cultivars with durable, high-temperature, adult-plant (HTAP) resistance and interaction of HTAP and race-specific seedling resistance to Puccinia striiformis. Phytopathology 85:573-578.

10. Chen, X. M., Moore, M., Milus, E. A., Long, D. L., Line, R. F., Marshall, D., and Jackson, L. 2002. Wheat stripe rust epidemics and races of Puccinia striiformis f. sp. tritici in the United States in 2000. Plant Dis. 86:39-46.

11. Cheng, P., Xu, L. S., Wang, M. N., See, D. R., and Chen, X. M. 2014. Molecular mapping of genes $\operatorname{Yr} 64$ and Yr65 for stripe rust resistance in hexaploid derivatives of durum wheat accessions PI 331260 and PI 480016. Theor. Appl. Genet. 127:2267-2277.

12. Han, D. J., Wang, Q. L., Zhang, L., Wei, G. R., Zeng, Q. D., Zhao, J., Wang, X. J., and Kang, Z. S. 2010. Evaluation of resistance of current wheat cultivars to stripe rust in Northwest China, North China and the Middle and Lower Reaches of Changjiang River epidemic area. Sci. Agric. Sin. 43:2889-2896.

13. Jia, Q. Z., Huang, J., Cao, S. Q., Zhang, B., Wang, X. M., and Jin, S. L. 2012. Discovery of new stripe rust strain infecting Chinese major wheat resistant material Guinong 22 and its preliminary pathogenicity analysis. Gansu Agric. Sci. Technol. 32:3-5.

14. Jousimo, J., Tack, A. J. M., Ovaskainen, O., Mononen, T., Susi, H., Tollenaere, C., and Laine, A. L. 2014. Ecological and evolutionary effects of fragmentation on infectious disease dynamics. Science 344:1289-1293.

15. Kang, Z., Zhao, J., Han, D., Zhang, H., Wang, X., Wang, C., Han, Q., Guo, J., and Huang, L. 2010. Status of wheat rust research and control in China. Pages 50-69 in: BGRI 2010 Tech. Workshop Oral Presentations, St. Petersburg, Russia.

16. Li, G., Li, Z., Yang, W., Zhang, Y., He, Z., Xu, S., Singh, R., Qu, Y., and Xia, X. 2006. Molecular mapping of stripe rust resistance gene $\mathrm{YrCH} 42$ in Chinese wheat cultivar Chuanmai 42 and its allelism with $Y r 24$ and $Y r 26$. Theor. Appl. Genet. 112:1434-1440.

17. Li, Z. Q., and Zeng, S. M. 2002. Wheat Rust in China. China Agriculture Press, Beijing.
18. Line, R. F., and Qayoum, A.1992. Virulence, aggressiveness, evolution, and distribution of races of Puccinia striiformis (the cause of stripe rust of wheat) in North America 1968-1987. U. S. Dep. Agric. Tech. Bull. No. 1788.

19. Liu, T. G., Peng, Y. L., Chen, W. Q., and Zhang, Z. Y. 2010. First detection of virulence in Puccinia striiformis f. sp. tritici in China to resistance genes Yr24 (=Yr26) present in wheat cultivar Chuanmai 42. Plant Dis. 94:1163.

20. Lu, Y., Wang, M. N., Chen, X. M., See, D., Chao, S. M., and Jing, J. X. 2014. Mapping of Yr62 and a small-effect QTL for high-temperature adult-plant resistance to stripe rust in spring wheat PI 192252. Theor. Appl. Genet. 127: 1449-1459.

21. Ma, J. X., Zhou, R. H., and Dong, Y. S. 2001. Molecular mapping and detection of the yellow rust resistance gene $\mathrm{Yr} 26$ in wheat transferred from Triticum turgidum L. using microsatellite markers. Euphytica 120:219-226.

22. McIntosh, R. A., Dubcovsky, J., Rogers, J., Morris, C., Appels, R., and Xia, X. C. 2014. Catalogue of gene symbols for wheat: 2013-2014 Supplement. Online publication. http://www.shigen.nig.ac.jp/wheat/komugi/genes/macgene/ supplement2013.pdf

23. McIntosh, R. A., Wellings, C. R., and Park, R. F. 1995. Wheat Rusts: An Atlas of Resistance Genes. Kluwer Academic Publishers, Dordrecht, The Netherlands.

24. Peterson, R. F., Campell, A. B., and Hannah, A. 1948. A diagrammatic scale for estimating rust intensity on leaves and stems of cereals. Can. J. Res. 26c: 496-500.

25. Qayoum, A., and Line, R. F. 1985. High-temperature, adult-plant resistance to stripe rust of wheat. Phytopathology 75:1121-1125

26. Rosewarne, G. M., Herrera-Foessel, S. A., Singh, R. P., Huerta-Espino, J., Lan, C. X., and He, Z. H. 2013. Quantitative trait loci of stripe rust resistance in wheat. Theor. Appl. Genet. 126:2427-2449.

27. Saghai-Maroof, M., Soliman, K., Jorgensen, R. A., and Allard, R. 1984. Ribosomal DNA spacer-length polymorphisms in barley: Mendelian inheritance, chromosomal location, and population dynamics. Proc. Natl. Acad. Sci. USA 81:8014-8018.

28. Sharma-Poudyal, D., Chen, X. M., and Rupp, R. 2014. Potential oversummering and overwintering regions for the wheat stripe rust pathogen in the contiguous United States. Int. J. Biometeorol. 58:987-997.

29. Sharma-Poudyal, D., Chen, X. M., Wan, A. M., Zhan, G. M., Kang, Z. S., Cao, S. Q., Jin, S. L., Morgounov, A., Akin, B., Mert, Z., Shah, S. J. A., Bux, H., Ashraf, M., Sharma, R. C., Madariaga, R., Puri, K. D., Wellings, C., Xi, K. Q., Wanyera, R., Manninger, K., Ganzález, M. I., Koyda, M., Sanin, S., and Patzek, L. J. 2013. Virulence characterization of international collections of the wheat stripe rust pathogen, Puccinia striiformis f. sp. tritici. Plant Dis. 97:379-386

30. Wan, A., Zhao, Z., Chen, X., He, Z., Jin, S., Jia, Q., Yao, G., Yang, J., Wang, B., Li, G., Bi, Y., and Yuan, Z. 2004. Wheat stripe rust epidemics and virulence of Puccinia striiformis f. sp. tritici in China in 2002. Plant Dis. 88:896-904.

31. Wan, A. M., and Chen, X. M. 2014. Virulence characterization of Puccinia striiformis f. sp. tritici using a new set of $Y r$ single-gene line differentials in the United States in 2010. Plant Dis. 98:1534-1542.

32. Wan, A. M., Chen, X. M., and He, Z. H. 2007. Wheat stripe rust in China. Aust. J. Agric. Res. 58:605-619.

33. Wang, C., Zhang, Y., Han, D., Kang, Z., Li, G., Cao, A., and Chen, P. 2008 SSR and STS markers for wheat stripe rust resistance gene Yr26. Euphytica 159:359-366.

34. Wellings, C. R. 2011. Global status of stripe rust: A review of historical and current threats. Euphytica 179:129-141.

35. Wellings, C., Singh, R., Yahyaoui, A., Nazari, K., and McIntosh, R. 2009. The development and application of near-isogenic lines for monitoring cereal rust pathogens. Pages 77-87 in: Proc. Oral Pap. Posters 2009 Tech. Workshop, Borlaug Global Rust Initiative, Cd. Obregón, Sonora, Mexico.

36. Wellings, C. R., Boyd, L. A., and Chen, X. M. 2012. Resistance to stripe rust in wheat: Pathogen biology driving resistance breeding. Pages 63-83 in Disease Resistance in Wheat. I. Sharma, ed. CAB International, Wallingford, UK.

37. Wen, W., Li, G., He, Z., Yang, W., Xu, M., and Xia, X. 2008. Development of an STS marker tightly linked to $\operatorname{Yr} 26$ against wheat stripe rust using the resistance gene-analog polymorphism (RGAP) technique. Mol. Breed. 22: 507-515.

38. Zadoks, J. C. 1961. Yellow rust on wheat studies in epidemiology and physiologic specialization. Eur. J. Plant Pathol. 67:69-256.

39. Zeng, S., and Luo, Y. 2006. Long-distance spread and interregional epidemics of wheat stripe rust in China. Plant Dis. 90:980-988.

40. Zhang, X. J., Han, D. J., Zeng, Q. D., Yuan, F. P., Shi, J. D., Duan, Y. H., Wang, Q. L., Wu, J. H., Huang, L. L., and Kang, Z. S. 2013. Fine mapping of wheat stripe rust resistance gene $\operatorname{Yr} 26$ based on collinearity of wheat with Brachypodium distachyon and rice. PLoS One 8, 3:e57885. 